\title{
DUKUNGAN KESEHATAN JIWA DAN PSIKOSOSIAL (DKJPS) COVID-19 PADA MASYARAKAT KATEGORI “ORANG SEHAT” DI DESA SERETAN KECAMATAN LEMBEAN TIMUR, SULAWESI UTARA
}

\author{
Wetik Virgini Syenshie ${ }^{1}$, Polii Benedikta Grace ${ }^{2}$, Lumowa Nissia Fressy ${ }^{3}$ \\ 1,2,3 Fakultas Keperawatan, Universitas Katolik De La Salle Manado \\ Email : sywetik@gmail.com
}

\begin{abstract}
ABSTRAK
Mewabahnya virus corona (COVID-19) saat ini, menjadi ancaman dan tantangan besar bagi seluruh negara di dunia, termasuk Indonesia. Hingga saat ini, jumlah penderita covid-19 terus meningkat. Berbagai upaya telah dilakukan oleh pemerintah namun belum menunjukkan penurunan jumlah kasus. Hal ini menimbulkan masalah baru (stressor) bagi masyarakat salah satunya adalah masalah psikologis. Beredarnya informasi yang tidak adekuat (hoax), kesulitan berinteraksi sosial, masalah ekonomi, ketidakpastian akan berakhirnya masa pandemi dan lainnya membuat masyarakat menjadi mudah khawatir, panik, khawatir, cemas, gelisah, stres, tertekan, takut dan berbagai masalah psikologis lainnya. Tujuan kegiatan ini adalah meningkatkan pengetahuan dan kemampuan mengatasi masalah psikososial bagi masyarakat di masa pandemi ini. Adapun kegiatan yang dilakukan yaitu pemberian edukasi (penyuluhan) dan latihan relaksasi bagi masyarakat kategori "orang sehat". Terdapat peningkatan pengetahuan dan kemampuan relaksasi pada masyarakat Desa Seretan Kecamatan Lembean Timur. Dengan demikian, pemberian penyuluhan ini memberikan banyak manfaat bagi masyarakat.
\end{abstract}

Kata Kunci : DKJPS, Covid-19, Orang Sehat, Penyuluhan Kesehatan

\section{ABSTRACT}

The outbreak of the corona virus (COVID-19) is currently a major threat and challenge for all countries in the world, including Indonesia. Until now, the number of people with Covid-19 continues to increase. Various attempts have been made by the government but have not shown a decrease in the number of cases. This creates new problems (stressors) for the community, one of which is a psychological problem. The circulation of inadequate information (hoaxes), difficulties in social interaction, economic problems, uncertainty over the end of the pandemic and others make people anxious, panic, anxious, anxious, anxious, stressed, depressed, afraid and various other psychological problems. The purpose of this activity is to increase knowledge and ability to overcome psychosocial problems for the community during this pandemic. The activities carried out consist of providing education (counseling) and relaxation exercises for the category of "healthy people" or not exposed to Covid. There has been an increase in knowledge and relaxation skills in the people of Seretan Village, East Lembean Regency. The conclusion is that this education provides many benefits for the community.

Keyword : Mental Health And Pyscosial Support, Covid-19, Healthy People Category, Health Education 


\section{PENDAHULUAN}

Penyebaran kasus virus corona (covid-19), menjadi ancaman serius dan tantangan terbesar bagi seluruh negara didunia, termasuk Indonesia. Jumlah kasus virus corona di seluruh dunia masih terus mengalami peningkatan. Melansir data Worldometers dalam Kompas tertanggal 23 Juli 2020 melaporkan bahwa, jumlah kasus virus corona tercatat sebanyak 15.347.848 kasus. Dari angka itu, 625.110 orang meninggal dunia dan jumlah yang sembuh sebanyak 9.332.230 orang. Berdasarkan laporan Gugus Tugas Nasional Percepatan Penanggulangan Covid-19 per-tanggal 27 Juli 2020 disebutkan bahwa 95.418 kasus terkonfirmasi positif, 36.808 kasus dalam perawatan $(38,6 \%), 53.945$ kasus dinyatakan sembuh $(56,5 \%)$, dan 4.665 kasus meninggal dunia $((4,9 \%)$ sedangkan 53.702 kasus suspek Covid-19.

Jumlah kasus baru positif Covid-19 di Sulawesi Utara meningkat signifikan dari waktu ke waktu dan dinyatakan dalam level masih tertinggi. Meskipun tidak terlaporkan dalam provinsi dengan kasus terbesar, namun Provinsi Sulawesi Utara berada pada posisi ke -11 dari total 34 provinsi di Indonesia dengan jumlah 2.162 kasus terkonfirmasi positif, 978 kasus dinyatakan sembuh dan 119 kasus meninggal dunia. hal ini menyebabkan berbagai upaya percepatan penanggulangan wabah Covid-19 telah dilakukan oleh pemerintah dengan memperhatikan berbagai aspek kehidupan masyarakat. Dimulai dengan peraturan dan kebijakan di lintas sektor sampai kepada kebijakan Penerapan Sosial Berskala Besar (PSBB), antara lain: 1) Peliburan sekolah dan tempat kerja; 2) Pembatasan kegiatan keagamaan; 3) Pembatasan kegiatan di tempat/fasilitas umum; 4) Pembatasan kegiatan sosial budaya; 5) Pembatasan moda transportasi; dan 6) Pembatasan kegiatan lainnya terkait aspek pertahanan dan keamanan. Hal tersebut dilakukan dalam upaya memperkecil meluasnya dampak penularan Covid-19 di masyarakat. Namun secara tidak langsung berbagai kebijakan tersebut menimbulkan stresor bagi masyarakat karena harus beradaptasi dengan situasi pandemi dengan instan termasuk penerapan berbagai protokol kesehatan baru sehingga sangat jelas berdampak pada psikososial masyarakat.

Berbagai dampak yang dirasakan sebagai pemicu masalah pikososial yaitu meningkatnya prevelensi kasus terkonfirmasi positif secara cepat di berbagai wilayah, beredarnya informasi yang tidak adekuat serta ketidakpastian akan keberhasilan program perawatan dan pengobatan pasien positif Covid-19 maupun ketidakpastian kapan pandemi ini berakhir, secara langsung menjadi sumber ancaman sehingga menyebabkan masyarakat menjadi mudah panik, cemas, gelisah, stres, merasa tertekan, takut dan bersikap maladaptif menghadapi situasi pandemi seperti ini (DKJPS, 2020).

Lembean Timur adalah salah satu kecamatan yang berada di wilayah Kabupaten Minahasa. Meskipun menempati poisi kedua dalam urutan kasus terkonfrimasi positif covid-19 di Sulawesi Utara, namun Kecamatan Lembean Timur adalah salah satu kecamatan di wilayah Sulut yang tidak memiliki kasus positif covid-19 sehingga dikategorikan sebagai green zone. Meski demikian, maka tidak berarti bahwa masyarakat di wilayah Kecamatan Lembean Timur terhindar dari permasalahan kesehatan jiwa dan psikososial terkait pandemi Covid-19. Hal ini bisa dilihat dari data yang ditemukan dilapangan bahwa beberapa warga mengatakan takut terpapar dengan virus corona, cemas bila bertemu dengan orang baru, dan lainnya yang mengindikasi adanya gangguan kecemasan. Berdasarkan paparan diatas, maka pemberian penyuluhan kesehatan tentang dukungan jiwa dan psikososial terkait pandemi covid-19 dirasakan perlu untuk dilaksanakan pada kecematan Lembean Timur, terlebih khusus pada wilayah desa Seretan, sehingga dapat meningkatkan pengetahuan warga dan 
memperkuat imunitas fisik dan jiwa dan menjadikan Desa Seretan menjadi wilayah dengan tingkat kesiapan yang adekuat dalam menjalankan adapttatanan/perilaku hidup baru (new normal) di masa pandemi Covid-19 ini.

\section{MASALAH}

Adapun alasan pemilihan lokasi penyuluhan kesehatan DKJPS COVID-19 pada kategori "orang sehat" di Desa Seretan, Kecamatan Lembean Timur ini adalah selain lokasi yang jauh dari pusat kota Manado yaitu $\pm 62 \mathrm{~km}$. Desa Seretan adalah salah satu wilayah administratif di Kecamatan Lembean Timur, Kabupaten Minahasa dengan jumlah kasus covid $=0 \%$ dalam kategori apapun. Sehingga Desa Seretan ini termasuk dalam kategori istimewa dengan istilah "green zone". Namun hal tersebut dibarengi dengan masih kurangnya pengetahuan warga tentang covid-19 pada hasil survey awal masalah kesehatan. Hal ini ditandai dengan masih ada beberapa kelompok warga yang bertanya tentang covid-19 dan penularannya, protokol kesehatan masih belum berjalan dengan baik, dan hasil wawancara tingkat ansietas terkait covid-19 ini, rata-rata berada pada kategori sedang - berat. Selain itu, belum ada upaya puskesmas dalam mengatasi masalah psikologis masyarakat terkait hal ini. Jauhnya jarak desa dengan pusat kota mengakibatkan wilayah ini menjadi kurang tersentuh dalam bidang kesehatan terlebih khusus kegiatan promosi kesehatan berupa penyuluhan kesehatan.
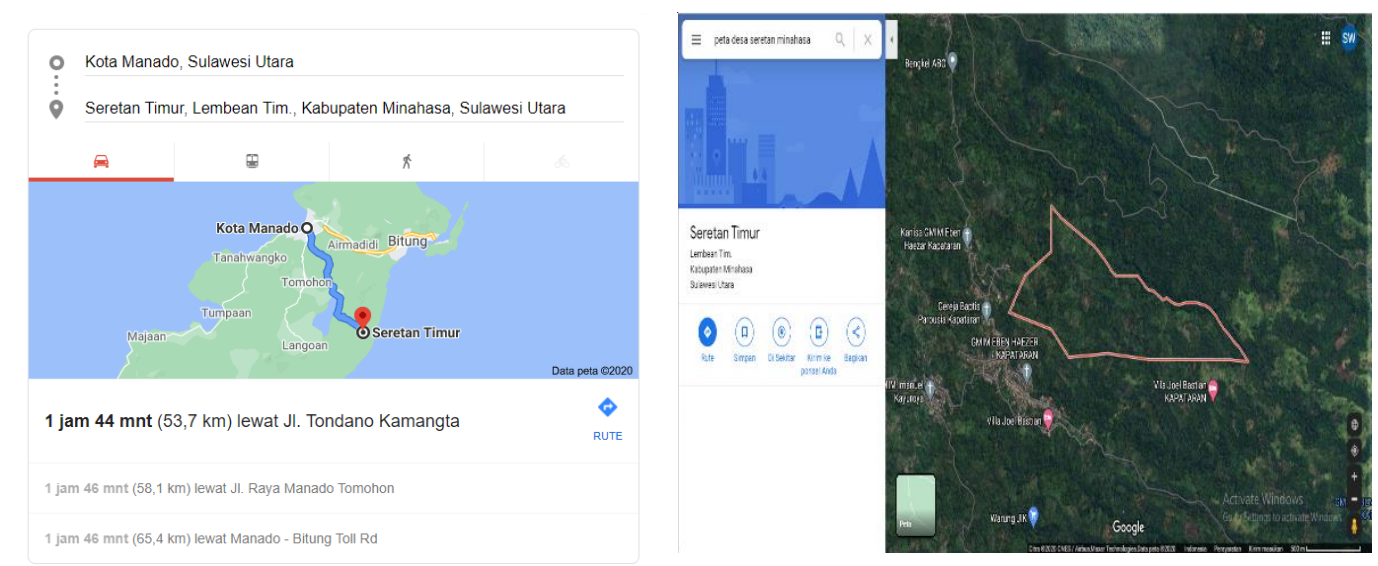

\subsection{Peta Lokasi Kegiatan Pengabdian Kepada Masyarakat}

\section{METODE}

Kegiatan penyuluhan kesehatan DKJPS COVID-19 pada kategori "orang sehat" di Desa Seretan, Kecamatan Lembean Timur ini menggunakan metode ceramah dan praktik menggunakan video (gerak dan lagu). Kegiatan ini dilakukan dengan cara mendatangi warga mayarakat usia dewasa dirumahnya masing-masing (accidental sampling). Metode ini dipilih karena saat pelaksanaan kegiatan bersamaan dengan pandemi covid-19 sehingga tim tidak mengumpulkan peserta penyuluhan pada satu lokasi sebagaimana biasanya. Seluruh proses pelaksanaan kegiatan mematuhi penerapan protokol kesehatan yang berlaku dan dikoordinir oleh pihak kelurahan dan kecamatan.

Adapun pelaksanaan kegiatan ini terbagi menjadi 3 tahapan yaitu :

1) Tahap persiapan, diawali dengan koordinasi dengan pihak kecamatan dan kelurahan, penyusunan pre-planning, pembagian kelompok (tim fasilitator), persiapan alat dan bahan 
2) Tahap pelaksanaan, tim melaksanakan kegiatan penyuluhan dengan cara langsung mendatangi rumah warga dengan bantuan kader kesehatan dan kepala lingkungan. Tim menjelaskan tujuan kegiatan, mengkaji pengetahuan awal tentang covid-19 dan skoring tingkat ansietas (pre-test), memberikan ceramah singkat tentang covid-19, ara penularan, cara pencegahan dan disertai latihan relaksasi mengatasi ansietas

3) Tahap evaluasi, meminta peserta penyuluhan termasuk keluarga yang mendampingi untuk menceritakan/ memperagakan kembali tentang materi dan latihan relaksasi yang diajarkan sebelumnya. Selanjutnya, mengkaji pengetahuan tentang pengetahuan dan kemampuan melakukan latihan relaksasi (post-test). Kegiatan ini berhasil menjangkau sebanyak 53 masyarakat dewasa (usia 30 - 60 tahun)

4) tahap lanjutan, memberikan video edukasi tentang latihan relaksasi yang sudah diajarkan melalui kiriman whatsapp/bluetooth kepada seluruh peserta penyuluhan maupun kepada kader kesehatan dan pimpinan desa agar dapat dijadikan sebagai bahan latihan maupun diagikan kepada warga masyarakat yang belum sempat mengikuti kegiatan ini. Hal ini dilakukan agar edukasi ini dapat diterima oleh seluruh masyarakat dan latihan relaksasi dapat dilatih secara kontinyu sehingga warga desa Seretan dapat memelihara kesehatan fisik dan psikologisnya di masa pandemi ini.

\section{HASIL DAN PEMBAHASAN}

Kegiatan penyuluhan kesehatan gigi dan mulut pada anak usia sekolah di desa Seretan, Kecamatan Lembean Timur ini berlangsung pada tanggal 11-12 Agustus 2020 dengan dibantu oleh 10 orang mahasiswa, 3 tokoh masyarakat, 3 kader kesehatan dan berhasil menjangkau sebanyak 53 masyarakat dewasa (usia 30 60 tahun). Seluruh proses pelaksanaan dapat dilaksanakan dengan baik sesuai dengan Planning of Action (POA). Adapun hambatan yang ditemui adalah, tidak semua masyarakat berada dirumah dikarenakan kegiatan dilangsungkan pada jam kerja, sebagian masyarakat berada diluar rumah (di kebun maupun tempat kerja lainnya). Selama proses pelaksanaan, para peserta penyuluhan sangat antusias menerima materi dan mampu mengikuti seluruh kegiatan dengan baik. Tidak ada peserta drop-out yang dilaporkan/ ditemui oleh tim. Adapun hasil yang didapatkan yaitu terdapat peningkatan pengetahuan yang sangat signifikan tentang pengetahuan dan kemampuan melakukan relaksasi akibat covid-19 pada seluruh peserta penyuluhan. Hal ini nampak pada hasil pre dan post-test. Seminggu setelah kegiatan pelaksanaan, kader kesehatan melaporkan bahwa peserta penyuluhan masih terus menerapkan prosedur merawat gigi dan mulut serta saling mengedukasi antar satu dengan lainnya dan kegiatan latihan relaksasi dijalankan dengan antusias.

Berdasarkan hasil yang didapakan tersebut terlihat bahwa kegiatan Dukungan Kesehatan Jiwa Psikososial (DKJPS) Covid-19 pada masa pandemi Covid-19 ini sangat diperlukan oleh masyarakat. Hal ini karena didalam kegiatan DKJPS akan diberikan pengetahuan secara kognitif dan psikomotor tentang pencegahan dampak fisik dan psikososial akibat covid-19 agar masyarakat (Keliat dkk, 2020)

Berikut ini dilampirkan foto kegiatan penyuluhan kesehatan DKJPS di Desa Seretan, Kecamatan Lembean Timur, Sulawesi Utara (Gambar 1) 

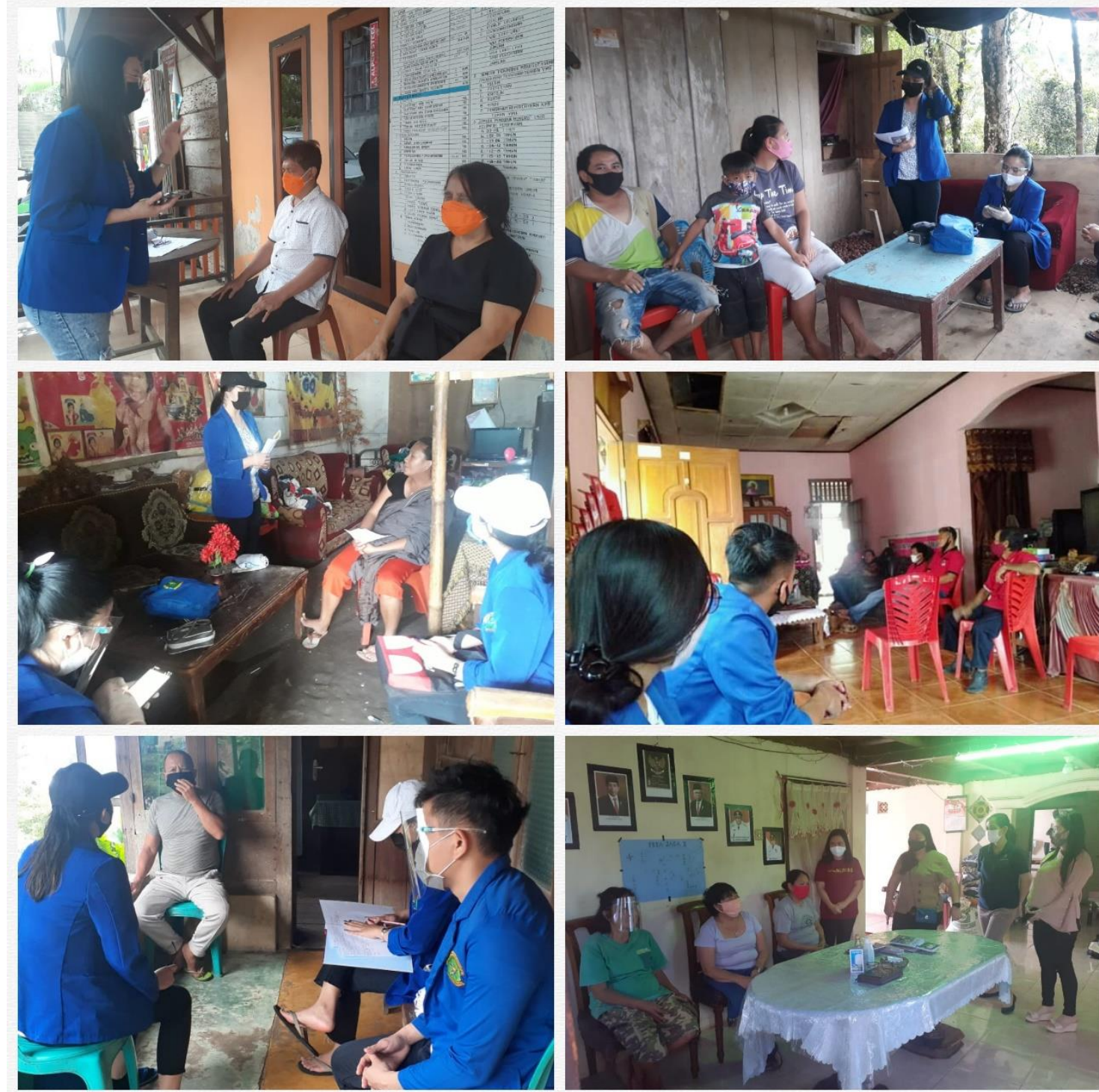

Gambar 2.2 Pelaksanaan Kegiatan PKM

\section{KESIMPULAN}

Adapun kesimpulan dari pelaksanaan penyuluhan DKJPS Covid-19 pada masyarakat kategori "orang sehat" di Desa Seretan, Kecamatan Lembean Timur yaitu seluruh peserta penyuluhan mampu memahami pengertian, tujuan, manfaat dari kegiatan penkes dan mampu mengaplikasikan cara mengatasi ansietas dan mempertahankan edukasi tersebut pada tindakan sehari-hari sehingga terjadi peningkatan pengetahuan dan sikap yang signifikan.

\section{UCAPAN TERIMA KASIH}

Tim pelaksana mengucapkan terima kasih kepada pihak Kecamatan Lembean Timut, Kepala Desa Seretan, Kader Posyandu dan seluruh masyarakat yang sudah membantu proses pelaksanaan kegiatan sehingga berjalan dengan baik. Dan teristimewa kepada seluruh peserta dan keluraga yang sudah sangat antusias mengikuti kegiatan ini. 


\section{DAFTAR PUSTAKA}

Keliat, dkk (2020) Mental Health and Psychosocial Support Covid-19: Keperawatan Jiwa. Fakultas Ilmu Keperawatan Universitas Indonesia.

Aida, R.N. (2020, Juli 23). Update Virus Corona Dunia 23 Juli 2020: 15,3 Juta Orang Terinfeksi https: / /www.kompas.com/tren/read/2020/07/23/082543665/updatevirus-corona-dunia-23-juli-2020-153-juta-orang-terinfeksiketegangan?page $=$ all, diakses tanggal 24 Juli 2020

Keliat, B. A., Hamid, A. Y. S., Putri, Y. S. E., Daulima, N. H. C., Wardani, I. Y., Susanti, H., Hargiana, G., \& Panjaitan, R. U. (2019). Asuhan keperawatan jiwa. Jakarta: Penerbit Buku Kedokteran, EGC

Kementerian Kesehatan RI (2019). Pedoman Pencegahan dan Pengendalian Coronavirus Disease (COVID-2019).

Kementerian Luar Negeri RI (2020, April 22) Kebijakan Pemerintah Republik Terkait Wabah Covid-19) https: / /kemlu.go.id/brussels/id/news/6349/kebijakan-pemerintahrepublik-indonesia-terkait-wabah-covid 19\#: : text=Peraturan\%20Pemerintah\%20Nomor\%2021\%20tahun,provinsi \%20atau\%20kabupaten\%2Fkota\%20tertentu. diakses tanggal 24 Juli 2020

Koernia. (2020, Mei 27). Covid-19 dan Bencana Nasional https: / / puspensos.kemsos.go.id/covid-19-dan-bencana nasional\#: : text=Kondisi\%20seperti\%20saat\%20sekarang\%20Ini,untuk\%20 menanggulanginya\%20agar\%20secepatnya\%20selesai. diakses tanggal 24 Juli 2020.

Putri, S.G (2020, Juni 11). WHO: Pandemi Covid-19 Memburuk, Bukan Saatnya Bersantai.

https://www.kompas.com/sains/read/2020/06/11/080400523/who-pandemi-covid-19-memburuk-bukan-saatnya-bersantai?page=all diakses tanggal 24 Juli 2020

Satuan Gugus Tugas Covid-19 Nasional RI (2020, Juli 20) https://covid19.go.id/peta-sebaran, diakses tanggal 24 Juli 2020

Satuan Gugus Tugas Covid-19 Provinsi Sulawei Utara (2020, Juli 23) https://corona.sulutprov.go.id/, diakses tanggal 24 Juli 2020

Utami, dkk (2020). Pedoman Dukungan Kesehatan Jiwa dan Psikososial Pada Pandemi Covid-19. Jakarta: Kementerian Kesehatan Republik Indonesia

WHO (2020) Mental health and psychosocial considerations during the COVID19 outbreak.

WHO (2020). https://www.who.int/indonesia/news/novel-coronavirus/qafor-public, diakses tanggal 24 Juli 2020. 